\title{
Ecuadorian Teachers' Perceptions of Teaching English: Challenges in the Public Education Sector
}

\author{
Agnes Orosz, Mirdelio Monzón and Paola Velasco \\ Universidad Nacional de Educación (UNAE), Azogues, Ecuador \\ https://orcid.org/0000-0002-1841-8320 \\ https://orcid.org/0000-0001-7831-0963 \\ https:/ / orcid.org/0000-0001-6587-5260
}

\begin{abstract}
The current English curriculum in Ecuador requires that highschool students graduate with an intermediate (B1) level. Attaining this target depends on several factors, such as teaching strategies employed in class and teacher training opportunities offered. Ecuador is ranked low for English language proficiency and, therefore, an exploratory approach has been used as the main data collection method to investigate the possible reasons for poor performance. In the previous phase of an overarching research project, round table discussions were held to explore themes related to English teachers' pedagogical practices. The data gathering process in the phase described in the present study involved conducting in-depth interviews with 10 primary and secondary school English language teachers. The transcribed interviews were analyzed by putting the material through the MAXqda qualitative analysis software. The resulting coded categories allowed the authors to investigate three specific issues dealt with in the present research study, namely: teachers' perceptions of the importance of learning English, actual classroom teaching practices, and the teachers' observations on inservice training options. The findings of the study demonstrate that English teachers in Ecuadorian public schools recognize the importance of English and are making a substantial effort to keep up with the professional demands related to teaching English as a Foreign Language, but they lack the required knowledge to develop skills, such as critical thinking and creativity. They are also facing several challenges, such as a demanding new curriculum and students' lack of motivation at a time of apparently dwindling teacher training opportunities.
\end{abstract}

Keywords: English language teaching; perceptions on English; English teaching curriculum; classroom teaching strategies; English teacher training 


\section{Introduction}

In Ecuador, the importance of learning English as a Foreign Language (EFL) has been acknowledged in several education policy documents, such as the National Curriculum Guidelines (Ministerio de Educación, 2013) and English as a Foreign Language (Ministerio de Educación, 2016a). The recognition of the need for learning English as a global language has resulted in curricular changes, whose aim is to build a solid foundation for authentic and culturally relevant language production as set out in the document titled Currículo de los niveles de Educación Obligatoria [Curriculum for the Compulsory Levels of Education] (Ministerio de Educación, 2016b).

Nevertheless, a recent survey carried out by Education First (2020a) shows that Ecuador ranks the last of the 19 surveyed Latin American countries in English language proficiency. In fact, in the annual ranking of 100 countries and regions, Ecuador slid from No. 81 in 2019 to No. 93 in 2020 (Education First, 2019; Education First, 2020b). Despite the requirements laid down in the curriculum, most students leave high school without reaching the required B1 level, meanwhile English teachers appear to be struggling with the application of upto-date methodology and language teaching strategies (Halim, 2017). An important question for inquiry could then be raised in this respect: what might be the reasons for the low results and the overall ineffectiveness of English teaching in this Latin American country?

Acosta and Cajas (2018) describe the attempts that Ecuador has been making to prioritize EFL in the education system, especially as education policy experts perceive English as an important communication tool for the country to succeed in a globalized world (British Council, 2015). However, there is growing realization that successful language policy changes require that policymakers are aware of the challenges English teachers are facing in their classrooms (Soto et al., 2020). In Ecuador, the new English teaching curriculum was launched in 2016 with the aim of introducing up-to-date methodology via promoting the use of technology and effective teaching-learning strategies throughout the country. The main tenets of the new curriculum are the inclusion of Content and Language Integrated Learning (CLIL), the application of Communicative Language Teaching (CLT), and the use of technology (ICT) for educational purposes (Ministerio de Educación, 2016a). The curriculum was last updated in 2018.

The most important addition is that high school students now need to graduate with an intermediate level of English, which corresponds to B1 on the six-point scale used by the Common European Framework of Reference for Languages (CEFR). However, since English is not among the subjects of the national secondary school leaving exam, only few students reach this level, which has a knock-on effect on those who then pursue tertiary education (Calle et al., 2012; Halim, 2017). The flagship state university of UNAE (Universidad Nacional de Educación [National University of Education]), whose researchers carried out the present research study, is committed to training a new generation of English teachers and is looking to establish best practices in teacher education. Therefore, it was deemed important to carry out an initial exploration of how English is being 
taught in public sector schools and how teaching and learning issues are perceived in primary and secondary schools by one of the main protagonists, namely, the teachers themselves.

To explore the strengths and weaknesses of English Language Teaching (ELT) in the public sector, a two-year research program was carried out from September 2018 to August 2020 at the university mentioned above. The overarching research project aimed at investigating the factors that foster or hinder the teachinglearning process of English as a Foreign Language in "Zone 6", which is comprised of three of Ecuador's provinces, namely: Azuay, Morona Santiago, and Cañar, representing about $10 \%$ of the country's population. As part of this wider research program, the authors of the present article are focusing on how English teachers perceive the importance of learning English, what teaching strategies they employ in their classrooms, and how far they feel they are supported in their work by in-service teacher training opportunities provided by the state. Overall, the research study offers further evidence that an exploratory and bottom-up approach provides rich data from the field which might help policymakers design interventions that can, in the long run, improve the quality of English language teaching in Ecuador.

\section{Literature Review}

\subsection{The Importance of Learning English}

English has undeniably emerged as the global language by the beginning of the $21^{\text {st }}$ century. Although it is difficult to establish how many people are fluent or competent speakers of the world's first truly global lingua franca, it is assumed that there are between 1.5 and 2 billion people (roughly one in four of the world's population) that speak English as a first, second or foreign language (Crystal, 2003; British Council, 2013; Cronquist \& Fiszbein, 2017). English is now incorporated into the curriculum of almost 140 countries including those of Latin America (Rojas \& Hernández-Fernández, 2018). Policymakers recognize the power of English (Chan, 2016) and the prospects it provides "ranging from ease of travelling abroad and participating in the global economy to opportunities to consume knowledge and media in other languages and to engage in diplomatic affairs" (Rojas \& Hernández-Fernández, 2018, p. 12). Research has shown that there is a correlation between the economic performance of a country and the English language proficiency of its population (McCormick, 2013). In addition, English language skills also provide opportunities at an individual level, and this is true for people who live in emerging economies such as Brazil and Mexico (Rojas \& Hernández-Fernández, 2018).

Even though the relevance of learning English is widely recognized on the whole of the South American continent, researchers remind us that there are two specific challenges in Latin America. One is that besides Spanish and Portuguese a number of indigenous languages are spoken in these countries. Second, owing to their colonial history, there might be sensitivity against a language that could be perceived as a threat to sovereignty (Rojas \& Hernández-Fernández, 2018). However, there is an acknowledgment that public policies should support societies that are both multilingual and intercultural (Starkey, 2010). 


\subsection{Teaching Strategies}

English Language Teaching (ELT) has changed profoundly in the past decades thanks to the work of applied linguists, the developments in teacher training methodology, and the creative approaches of classroom practitioners (Richards, 2015; Herrell \& Jordan, 2020). Hinkel (2006) described four themes that have changed policy makers' and teachers' perspectives on how English as a Second Language (ESL) or English as a Foreign Language (EFL) can be taught more effectively. These themes are listed as the decline of methods, the need to use bottom-up and top-down skills, the incorporation of new knowledge on the English language itself, and an acknowledgment that language skills need to be taught in context and in an integrated manner. Hinkel (2006) emphasized that "these factors have had a profound influence on classroom instruction and curriculum development in practically all L2 skills and across learner proficiency levels" (p. 110).

Another trend that has evolved is the result of the realization that $21^{\text {st-century }}$ language teaching has to prioritize elements that predispose learners to lifelong learning and engagement. This implies the integration of the so-called $4 \mathrm{Cs}$ (communication, critical thinking, creativity, and collaboration) into the four language skills: listening, speaking, reading, and writing (Erdoğan, 2019; Chiruguru, 2020). The list can be extended by adding digital literacy (Dudeney, 2015), citizenship and student leadership, and personal development (Norris, 2019).

\subsection{English Language Teaching Strategies in Ecuador}

The 57-page in-depth report prepared by the British Council (2015) examined the policies, perceptions, and factors that influenced the teaching of English in Ecuador since the early 1990s. The Ministry of Education and Culture and the British Council launched the so-called CRADLE project in 1992 to reform the English curriculum in public and semi-public schools (the latter run by the central government and religious orders). The report emphasized that CRADLE aimed at focusing on the four language skills (rather than using the grammar-translation method exclusively), included the designing of a series of textbooks that were appropriate in the Ecuadorian context, and provided technical assistance to the English teachers employed in the public education sector.

English language policy in Ecuador was reformed in 2012 (Macías Mosquera \& Villafuerte Holguin, 2020; Ministerio de Educación, 2013) and then again in 2016 (Ministerio de Educación, 2016a). In their study on English language teaching in an urban setting, Burgin and Daniel (2017) focused on the language teaching pedagogy of nine English teachers working at a public secondary school. The observations identified many positives about the teachers' instructional practices, which the authors attributed to "the impact of systemic governmental movements and expenditures" in the preceding years (Burgin \& Daniel, 2017, p. 114). However, they also pointed out that the instruction at the school was still mainly teacher-led, and critical thinking paradigms and learner empowerment were not in evidence. 


\subsection{Recent Relevant Literature}

There have been several recent studies conducted in teaching English in the public sector in Ecuador. In this respect, Calle et al. (2012) and Halim (2017) concluded that English proficiency levels were low due to English teachers' traditional classroom methodology (e.g., grammar-translation). Ortega and Minchala (2019) also drew attention to the low levels of English performance at secondary level, both in urban and rural areas. Suasnavas (2018) recommended that the teaching practices in public schools need to be examined in order to determine the specific weaknesses of the teaching/learning process, as well as to promote the implementation of new teaching strategies. The above-mentioned studies also refer to the challenges that teachers face since they find the implementation of the latest curriculum very demanding, mainly because the material contained in the course books cannot be covered owing to the insufficient number of English classes in primary and secondary schools.

\subsection{Teacher Training}

In-service teacher training has always been considered an essential element in the professional development of ELT teachers (Dikilitaş \& Erten, 2017; Richards \& Farrell, 2005). From Estonia (Raud \& Orehhova, 2017) through to Turkey (Koç, 2016) and Colombia (Buendía \& Macías, 2019), there is widespread agreement that there are common elements that need to be included in the training of teachers, and some of these are specific to teachers in an EFL setting, such as the improvement of language proficiency. Based on 25 empirical studies conducted in Colombia, Buendía and Macías (2019) included a comprehensive list of aspects to be considered (beyond language proficiency): "research skills and reflective practice, teachers' beliefs and identities, an integrated approach to teacher professional development, pedagogical skills and teaching approaches, and emerging technologies"(p. 98).

In the Ecuadorian context, relevant literature also points to the need for continuing professional development (Burgin \& Daniel, 2017) leading to new instructional approaches, such as problem-solving pedagogy and co-designing "new ways of interacting" (p. 121), especially in multilingual and multicultural settings - the reality of Ecuador today. Suasnavas (2018) likewise drew attention to the need for sustained teacher training programs. Having found low levels of English performance at secondary levels both in urban and rural areas, Ortega and Minchala (2019) also recommended that regular in-service training programs should be set up. Meanwhile, Soto et al. (2020) emphasized the need for the enhancement of student-centered approaches, adding that transformation will only start in class when teachers have the skills and pedagogical knowledge to apply language teaching strategies and techniques correctly. Finally, Halim (2017) stressed the need for improved training courses for pre-service teachers, the designing of which would require the re-thinking of the language teaching methodology component of teacher education. 


\section{Methodology}

\subsection{Research Design}

The present exploratory study was carried out in the second phase of a large-scale research project, which ran from September 2018 to August 2020 with funding secured through the National University of Education, Ecuador (known as UNAE by its Spanish acronym). The researchers aimed to carry out "a broad-ranging, purposive, systematic and prearranged undertaking designed to maximize the discovery of generalizations leading to description and understanding of social... life" (Vogt, 1999. p. 105). Translated into the present research project, the intention was to obtain exploratory qualitative data through in-depth interviews with teachers from three provinces of Ecuador, namely: Azuay, Cañar, and Morona Santiago. These three provinces were selected because they belong to the same administrative region (Zone 6) and the university (UNAE) is situated within this political and geographical area. The three neighbouring provinces cover a substantial area of the country, and have a large number of teachers working in public education institutions. The issues explored in the interviews and contained in the interview guide were based on the themes that had been identified in several round-table discussions held with a group of 40 teachers preceding the recording of the interviews (see Appendix 1).

\subsection{Participants}

To gain deeper insights, the researchers conducted in-depth interviews with 10 teachers out of the full cohort of 40 that participated in the round-table discussions. All teachers had a B2 (CEFR) level of English and were teaching in public schools at the time when the research was carried out. Four of them worked in primary schools, two of them were employed in secondary schools and four of them were 'hybrid' teachers, who worked at both primary and secondary levels at the time the interviews were conducted. The teachers participated voluntarily and were informed that they could withdraw from the project at any point in time. They each signed a consent form stating that they were participating voluntarily. Furthermore, the names of the participants and their educational institutions were kept anonymous (referring to them as T1, T2 ... T10).

The two pre-conditions that the researchers had set were that the teachers needed to have a minimum of two years of teaching experience and they needed to have participated in the first phase of the study, which meant that they had already taken part in the round-table discussions. The reason for this requirement was that the teachers were expected to be familiar with the initial themes arising from the round-table discussions, following which the researchers aimed to learn more about the teachers' feelings, perceptions and beliefs via the in-depth interviews. The 10 interviewees, who were selected from the 40 participants, exhibited the defining characteristics that were deemed important for the exploratory part of the present research. Furthermore, the 10 selected teachers were cooperating teachers in different programs, such as UNAE's Practicum and Community Outreach Programs.

The interviews were conducted in Spanish because this allowed the participants to discuss complex issues in the mother tongue without the pressure of having to 
use L2 for the exploration of their ideas. Their contributions were translated from Spanish into English by the investigators of the present research study. The translations were prepared independently by two of the three authors and then compared and matched for accuracy.

\subsection{Data Analysis}

The in-depth interviews were transcribed and then analyzed by putting the material through the MAXqda qualitative analysis software. MAXqda is considered to be a useful tool, suitable both for data processing and the coding of qualitative data (Godau, 2003). The process resulted in a list of categorized topics, which allowed the grouping of related ideas together. For the purposes of the present study, the researchers focused on three main topics:

- The importance of English as perceived by teachers working in primary and secondary public schools;

- Teaching strategies applied by teachers in order to achieve the goals set out by the curriculum; and

- The degree to which in-service teacher training is seen as helping teachers to achieve their goals.

\section{Findings}

This section discusses the findings related to the above-mentioned three issues: the importance of learning English, teaching strategies, and in-service teacher training. These three topics are intertwined and their relationship is further examined in the discussion section. All quotes below were taken from the categorized topic grid that was created as the result of the qualitative analysis accomplished by the MAXqda software.

\subsection{Perceived Importance of English in Basic and Secondary Education}

Ecuadorian English teachers appear to be acutely aware of the importance of learning English as a global language. One of the reasons mentioned is its significance for the tourist sector and foreign trade relations. Another reason is related to the fact that students need English for their further studies, including MA and Ph.D. programs, often combined with opportunities to win scholarships. The potential of higher earnings by professionals who speak English is also acknowledged. Teachers stressed that English is an international language, which is also used most extensively on the Internet and social media. Altogether, eight teachers gave specific reasons why they thought that English is important for their students. In the interviews with T8 and T10, there was no mention of this aspect, while the rest of the teachers cited several arguments in favor. 
Table 1. Why is English Important?

\begin{tabular}{|c|c|}
\hline $\begin{array}{l}\text { Arguments: } \\
\end{array}$ & Mentioned by: \\
\hline $\begin{array}{ll}\text { Economic reasons: } \\
\text { - Tourism } \\
\text { - } \quad \text { Foreign trade relations } \\
\text { - } & \text { Transmission of business } \\
& \text { ideas }\end{array}$ & $\mathrm{T} 1, \mathrm{~T} 7, \mathrm{~T} 9$ \\
\hline $\begin{array}{l}\text { Academic reasons: } \\
\text { - Essential for further studies } \\
\text { - Useful when doing MAs or } \\
\text { PhDs abroad } \\
\text { - Valuable when applying for } \\
\text { scholarships in-country or } \\
\text { abroad }\end{array}$ & $\mathrm{T} 1, \mathrm{~T} 2, \mathrm{~T} 5, \mathrm{~T} 6$ \\
\hline $\begin{array}{l}\text { Global communication reasons: } \\
\text { - Access to the Internet and } \\
\text { social media } \\
\text { - Enables user to communicate } \\
\text { internationally }\end{array}$ & $\mathrm{T} 3, \mathrm{~T} 4$ \\
\hline $\begin{array}{l}\text { Other reasons: } \\
\text { • Better professional jobs } \\
\text { - Higher earnings }\end{array}$ & $\mathrm{T} 2, \mathrm{~T} 5$ \\
\hline
\end{tabular}

\subsubsection{Teachers' Voices}

While teachers appeared to be adamant that learning English is paramount for their students, some interviewees believe that their students do not treat English as a priority and neither does Ecuadorian society at large:

I think we live in a society that does not attach too much importance to English and, as a result, our students don't think it is important, either. They don't do their homework, but this is true for other subjects, too. (T2)

Another teacher highlighted the socio-economic circumstances that seem to lie behind the lack of motivation:

The students in our high school come from dysfunctional families, in most cases, the parents live in the United States, so these kids are kind of orphans who live with their grandparents and all they want is to get their school-leaving exam certificate. (T5)

Overall, teachers do recognize the importance of learning English, but this does not seem to be reflected in their students' level of proficiency. To discover the possible reasons for the apparent mismatch between teacher perceptions and learning outcomes, it is crucial to take stock of the teaching strategies that teachers claim they employ in their classrooms.

\subsection{Teaching Strategies}

The primary and secondary teachers who were interviewed gave an account of an array of teaching strategies that they use. Table 2 summarizes the approaches and tools that have been mentioned in the course of the interviews. 
Table 2. Teaching Strategies Employed in the English Classroom

\begin{tabular}{|c|c|c|c|}
\hline Strategies & Tools & $\begin{array}{l}\text { Teachers' } \\
\text { remarks }\end{array}$ & $\begin{array}{l}\text { Mentioned } \\
\text { by }\end{array}$ \\
\hline \multicolumn{4}{|c|}{ Teaching the 4 skills } \\
\hline & CDs & \multirow{4}{*}{$\begin{array}{l}\text { No Internet, } \\
\text { daily use of CDs }\end{array}$} & \\
\hline \multirow{3}{*}{ Listening } & Using own mobile and mini- & & 15 \\
\hline & speakers & & T7 \\
\hline & $\begin{array}{l}\text { Language lab to watch movies } \\
\text { and songs }\end{array}$ & & T9 \\
\hline Speaking & $\begin{array}{l}\text { Active use of language } \\
\text { (greetings, classroom } \\
\text { instructions) }\end{array}$ & \multirow{4}{*}{$\begin{array}{l}\text { Students don't } \\
\text { always } \\
\text { understand the } \\
\text { text or find it } \\
\text { useful }\end{array}$} & $\mathrm{T} 7$ \\
\hline Reading & $\begin{array}{l}\text { Using the textbook and } \\
\text { provide extra information }\end{array}$ & & T9 \\
\hline \multirow[t]{2}{*}{ Writing } & $\begin{array}{l}\text { Dictation in group work, } \\
\text { active practice }\end{array}$ & & T6 \\
\hline & $\underline{\text { Methodology }}$ & & \\
\hline $\begin{array}{l}\text { Introducing new } \\
\text { material }\end{array}$ & $\begin{array}{l}\text { Relying on previous } \\
\text { knowledge }\end{array}$ & $\begin{array}{l}\text { E.g., Discussing } \\
\text { Ecuadorian } \\
\text { traditions }\end{array}$ & $\mathrm{T} 4$ \\
\hline \multirow{3}{*}{$\begin{array}{l}\text { Presentation of new } \\
\text { material }\end{array}$} & Interactive whiteboard & \multirow{9}{*}{$\begin{array}{l}\text { Last lesson of } \\
\text { the week }\end{array}$} & T6 \\
\hline & Using visual materials, & & T3 \\
\hline & Videos & & $\mathrm{T} 1$ \\
\hline Systematic revision & & & T3 \\
\hline $\begin{array}{l}\text { Personalized } \\
\text { attention }\end{array}$ & & & $\mathrm{T} 2$ \\
\hline $\begin{array}{l}\text { Practice and } \\
\text { assessment }\end{array}$ & Worksheets & & $\mathrm{T} 1$ \\
\hline $\begin{array}{l}\text { Vocabulary } \\
\text { expansion }\end{array}$ & Flashcards & & T5 \\
\hline \multirow{3}{*}{$\begin{array}{l}\text { Appealing to } \\
\text { cooperative and } \\
\text { competitive skills }\end{array}$} & Games & & $\mathrm{T} 2$ \\
\hline & Bingo & & $\mathrm{T} 2$ \\
\hline & \multirow{2}{*}{\multicolumn{2}{|c|}{$\begin{array}{r}\text { Extracurricular activities } \\
\text { Singing songs on Open Days }\end{array}$}} & \\
\hline Presentations & & & T6 \\
\hline $\begin{array}{l}\text { Using English in the } \\
\text { school playground }\end{array}$ & & \multirow[t]{2}{*}{$\begin{array}{l}\text { Greetings, } \\
\text { numbers, } \\
\text { instructions }\end{array}$} & $\mathrm{T} 2$ \\
\hline $\begin{array}{l}\text { Theatrical } \\
\text { performance and } \\
\text { singing on the patio }\end{array}$ & & & T3 \\
\hline
\end{tabular}


Alongside the teaching strategies involving methodological approaches and specific tools or activities, the teachers also described the challenges that they face in their daily work:

- Class size: 35-40 students in a group

- Crowded classrooms (often too hot or too cold)

- Class hours: 3-5 hours per week (40-minute classes) - not enough time to practice and internalize the material

- Lack of exposure to English outside school

- Unrealistic and unachievable curriculum

- Assessment: English is not among the subjects of the national schoolleaving exam

- Overworked and underpaid teachers (low social status)

- Lack of support from parents

- Low levels of knowledge in Spanish (especially in the case of indigenous students, for whom Spanish is a second language)

- Students' lack of motivation to learn English (or other subjects)

- Regulations favoring students (leniency)

- General issues with discipline (students playing and fighting with each other rather than paying attention)

\subsubsection{Teachers' Voices}

As has been stated before, one of the main tenets of the 2016 curriculum is the application of what is widely termed as Communicative Language Teaching or CLT (Ministerio de Educación, 2016a), an approach that also encourages group work and the use of cooperative learning. Some of the teachers interviewed were in favour of using the activities arising from the principles of CLT:

I like to use the communicative method, especially role plays, where they can apply straight away what they have learned... And what I like best is cooperative learning where the students can help each other... This is because we have a great disadvantage in public schools: we may have 35 and even 40 students in the classroom and it is impossible to deal with everyone individually. But when we use cooperative learning, the students work together. (T4)

The teachers used group work or pair work as well, whereby they utilized the multi-level groups to their students' advantage:

When they are using worksheets, the older ones work in pairs or groups, especially, when we have a double class. But it is the same with the younger ones, because they can help each other in case one of them did not understand what I said and the other understood it first time round. (T1)

Many teachers believe that the amount of English input is insufficient to gain an acceptable level of proficiency because English is a foreign and not a second language in Ecuador, which means that there are only few opportunities to practice the language outside class. On average, primary school students have three English classes of 40 minutes, this increases to five classes of 40 minutes in Year 8 and 9, but is decreased again to three hours per week in Year 10 when students are preparing for their final school-leaving exam. A further challenge 
might be that it is difficult to cater for students who are more advanced than the majority of the students in a given class:

In my opinion, we should have more English classes ... perhaps we could take away a couple of hours from other subjects. Also, we would need to do some streaming as it is done in other institutions because at times you can have an advanced student and a beginner in the same class. (T3)

Apart from not having enough classes, teachers often feel that the material that they need to cover is far too much:

We are told we have six weeks to finish one unit in the book, but each unit has six topics and six sets of tasks, so it is practically impossible to finish one topic in one week. In Ecuador we often do not have six weeks of teaching without a break, so we do not have enough time for practice... We then straight away have to start a new unit, which is often not connected at all to the previous one. (T4)

The following aspect to be looked at is the issue of the set course book and how far teachers feel they can identify with it. Some of the respondents of the research study were not thoroughly pleased with the course book. Teachers' dislike for the textbook they are required to use may be rooted in the fact that they feel the topics dealt with are far removed from the local context, as was stated by this secondary school teacher:

Sometimes the topics are a little complicated and they sound a bit strange, too, and in actual fact, I don't like them much at all... (T1)

On the whole, it appears that primary and secondary school English teachers use a variety of teaching strategies (which are mostly in line with the CLT approach) as well as a range of activities and tools, while they are facing a number of challenges that characterize not only Ecuador, but also other countries in Latin America (Rojas \& Hernández-Fernández, 2018).

\subsection{In-service Teacher Training}

Meaningful and appropriate teacher training is one of the most important elements that can improve the quality of the teaching-learning process. In-service training has the advantage of providing support to teachers who already have class experience and can transfer knowledge into their classrooms without any delay. While there have been serious efforts to reform how English is being taught in Ecuador, it seems that teacher training, and especially in-service teacher training, has been lagging behind. Table 3 demonstrates the various types of training that the interviewees had access to over the period when the research study was conducted. 
Table 3. Types of In-service Training for English Teachers in Public Schools

\begin{tabular}{lll}
\hline & \multicolumn{1}{c}{$\begin{array}{c}\text { Providers of teacher } \\
\text { training } \\
\text { in 2016-2017 }\end{array}$} & $\begin{array}{c}\text { Availability in 2018- } \\
\text { 2019 }\end{array}$ \\
\hline $\begin{array}{l}\text { Training sessions at the } \\
\text { school }\end{array}$ & $\begin{array}{l}\text { Lanincial English } \\
\text { Publishers (Cambridge }\end{array}$ & No \\
& $\begin{array}{l}\text { University Press, Oxford } \\
\text { University Press) }\end{array}$ & Yes \\
$\begin{array}{l}\text { Training courses at state } \\
\text { universities }\end{array}$ & $\begin{array}{l}\text { University of Cuenca } \\
\text { UNAE }\end{array}$ & No \\
$\begin{array}{l}\text { Scholarships } \\
\text { External sources }\end{array}$ & $\begin{array}{l}\text { Go Teacher } \\
\text { Peace Corps volunteers }\end{array}$ & Yes \\
$\begin{array}{l}\text { Self-initiated professional } \\
\text { development }\end{array}$ & Online courses & No \\
\hline
\end{tabular}

\subsubsection{Teachers' Voices}

Over the past years, Ecuadorian teachers could see how English as a Foreign Language (EFL) has gained increasing importance in this Latin American country (British Council, 2015), and how the official acknowledgment of those changes has led to a new set of requirements. English is perceived as an important school subject for the country's social and economic development and the expectation is that language teachers should have the right qualifications:

Some time ago anybody could teach English, even if they did not speak the language well, because nobody took much interest in it as a subject. But now we are being evaluated all the time and training sessions are also being set up. (T5)

However, some teachers mentioned that there were no systematic teacher training sessions in their schools; one of them added that this might have been due to the fact that s/he was a new teacher at the school. It is worth mentioning that up until 2016, there was another course book series in circulation titled Our World through English (Rosero et al., 2004), and it appears that at that time teacher training sessions were organized in a more systematic fashion at provincial level:

We had regular training sessions because there were coordinators in each province. Ours was very active, he called us every month for a training session and we got to know all the other English teachers as well. He chose some topics from the book, but he also added others and taught us grammar, too. (T5)

Besides the frequent sessions provided by the provincial English Language Coordinators, the state university of the regional capital, Cuenca, also played an important role in supplying in-service training. Owing to recent government policies (leading to budget cuts in education), teacher training programs tapered off at a time when paid-for courses for professional development are often beyond 
teachers' means, especially after the salary cuts introduced in the wake of the COVID-19 epidemic:

Four-five years ago we had training sessions at the State University of Cuenca and I always went to the workshops there. With this new government so much has been lost: now there is no state institution that carries out this task, and private courses are not available to teachers because of the high cost. (T9)

Teachers also said that even when there are training sessions, they are often unable to attend because of the high number of contact hours and the clashes in their timetables (T10). One of the ten teachers mentioned that $\mathrm{s} /$ he benefited a lot from the so-called Go Teacher program, which began in 2012 as a partnership between Kansas State University and Ecuador's governing body of higher education, the National Secretary of Higher Education, Science, Technology and Innovation (SENESCYT). The program provided an opportunity for approximately 1000 Ecuadorian English teachers to improve their language and teaching skills for seven months at Kansas State University and other partner institutions in the US:

I was one of the teachers who won a scholarship of the Go Teacher program, it went well for me, I was able to finish my studies and do all the tasks and participate in all the projects that were set for us. (T9)

In sum, the respondents' perception is that while there is a requirement to employ properly trained English teachers, whose performance is scrutinized more closely than before, the range and quality of the training sessions may vary. Furthermore, multiple respondents highlighted the fact that training sessions had been better organized and more frequent before the severe budget cuts in the education sector were implemented in recent years.

\section{Discussion}

English language teaching education has been a central issue for educational policy in Ecuador for almost a decade (Ministerio de Educación, 2013; 2016a; 2016b). However, recent results suggest that for language policy changes to succeed, policymakers should take into account the challenges encountered by English teachers in their daily practice (Acosta \& Cajas, 2018).

The present exploratory research study found that many of the challenges that were identified by recent studies have been confirmed by the participating 10 English teachers. Low proficiency levels were mentioned by several teachers, corroborating the findings of Calle et al. (2012) and Halim (2017). These authors concluded that one of the reasons for poor performance is the fact that teachers use traditional classroom methodology. As opposed to this, the teachers in the present survey were able to refer to an array of classroom tools and pedagogies that they were applying in order to make learning more effective. However, the teaching strategies applied are often limited by a number of challenges in the classroom, such as lack of motivation, insufficient number of English classes, and the fact that for indigenous students English is not the first, but the second additional language. 
The primary and secondary school teachers interviewed for the present exploratory study are fully aware of the importance of learning English as a Foreign Language. They recognize that Ecuadorian students need to be able to use English proficiently for trade and tourism, further studies abroad, and better-paid jobs and professional advancement. This, to some extent, is in line with the British Council report (2015), which surveyed the reasons given by learners as to why they studied English. While a high percentage of students mentioned that they studied English because it was compulsory in primary and secondary school $(34 \%$ and $52 \%$, respectively), they also mentioned that they needed English for their university studies or in order to improve their employment prospects, and have access to information in English.

One can argue that the low levels of language proficiency in the public education sector in Ecuador are not so much the result of ill feelings about the language itself (Rojas \& Hernández-Fernández, 2018), but can, to some extent, be explained by the challenges that indigenous students face when studying not a second but a third language. Rojas and Hernández-Fernández (2018) are clear about the tasks that Latin American governments need to set themselves so that they can "... provide indigenous communities education services that integrate them into society (by teaching in the official language); and ... respect and preserve their identity by providing a curriculum adapted to their mother tongue and ethnic customs" ( $p$. 19). In fact, the British Council report (2015) makes a mention of how diversity affects English learning in Ecuador when it says that being educated in the mother tongue is enshrined in the Ecuadorian Constitution, however, this means that education systems can differ from region to region, which "presents a challenge for the implementation of national education reforms and English language learning initiatives" (p. 53). Some of the interviewees have indeed mentioned how these challenges manifested themselves in their classrooms.

The teaching strategies applied by the 10 teachers appear to be varied and in line with the basic tenets of Communicative Language Teaching, although Cajas and Acosta (2018) emphasized that in Ecuador, "the nature, purpose and use of the CLT as the pedagogical approach of the CEFR is apparently not well understood and interpreted" (p. 102). This is not a unique phenomenon. For example, Mai (2007) stresses that even though teachers in Vietnam recognize the importance of communication skills, they still feel the need to accommodate the local context, in which more traditional approaches are deemed either useful or are probably expected. Similar issues, such as the employment of teacher-fronted noncommunicative activities, have been raised in Japan (Sakui, 2004), South Korea (Beaumont \& Chang, 2011), Iran (Sarab et al., 2016), and Thailand (Promtara \& Suwannarak, 2018).

The teachers who were interviewed usually give due emphasis to the four basic skills of listening, speaking, reading and writing and use the tools that are at their disposal (CDs, mobiles, language labs), and furthermore, they utilize the opportunities that extracurricular activities can offer, such as using English in the school playground or setting up theatrical performances and karaoke singing contests. However, it seems that they are only incorporating two of the so-called 
4Cs (communication, collaboration, creativity, and critical thinking), namely, communication and collaboration, while critical thinking and creativity do not appear to be integrated into the teaching-learning process. The development of these two skills might be perceived as a need for improvement, since the $4 \mathrm{Cs}$ are considered to be essential skills (Chiruguru, 2020; Erdoğan, 2019) because the knowledge of the four basic language skills, namely listening, speaking, reading and writing is not considered sufficient any longer. As Chiruguru (2020) put it succinctly when he said "if today's students want to compete in this global society, ... they must also be proficient communicators, creators, critical thinkers and collaborators" (p. 2).

The challenges that the teachers face are typically shared in the whole Latin American region (Carrier, 2018) including: large classes, too few class hours, lack of exposure to English outside school, limited resources, overworked and underpaid teachers with low social status. Ecuadorian teachers are aware that many of their students are socio-economically disadvantaged, but they also mention a general lack of motivation as well as some discipline issues. Furthermore, the interviewees often seem to struggle owing to the demands of the curriculum and the difficulty level of the course books. These challenges are acknowledged in the British Council report (2015), which additionally highlights the shortage of properly-trained and experienced English language teachers.

Recent studies (Suasnavas, 2018; Ortega \& Minchala, 2019; Soto at al., 2020) have recurrently pointed out that in order to achieve better learning results, sustained teacher training programs are required and these should involve training courses both for pre- and in-service teachers. Based on the teachers' account, it seems that in-service training opportunities for teachers have dwindled in the past couple of years because of a series of austerity measures that have been introduced in Ecuador since 2018. In 2020, the country's public debt reached almost $70 \%$ of its GDP, and the government cut public spending for education steeply (USD 142m in 2019 and $578 \mathrm{~m}$ in 2020). Teachers' salaries were reduced by $20 \%$ on average (Gómez Ponce, 2020; Iturralde, 2020). The severe cuts have probably affected the quantity and quality of opportunities for teachers' continuing professional development. Teachers used to participate in training sessions provided by provincial English Language Coordinators, and Cuenca State University also offered a range of teacher training courses but these have ceased to exist. These tasks, to some extent, have been taken over by UNAE (the other state university of education in Azuay province), however, teachers are not always able to participate owing to the high number of contact hours and clashes with their timetables.

Altogether, in-service teacher training is sporadic and less effective than before 2017. The Go Teacher program, which allowed approximately 1000 English teachers to spend about 7 months in the US studying at several universities between 2012 and 2016, may have had a beneficial effect on teachers' effectiveness, but to the best of the researchers' knowledge, so far there has been no research conducted on its success. The British Council report (2015) cites anecdotal evidence which suggests that "the exposure to native English teachers and culture 
gained through the programme is invaluable and that teachers have returned with improved English language and pedagogical skills" (p. 54). However, it is unclear how these positive outcomes may have been translated into more effective English teaching, first and foremost, in rural areas. Many of the teachers that took part in the Go Teacher program, especially those who were selected to study for MA degrees, have by now moved to tertiary education, and even though this might have a ripple effect on English teaching in the future, most of these teachers do not presently operate in low-resource primary and secondary classrooms.

\section{Conclusion}

The perceived importance of English, classroom strategies, and in-service teacher training are interrelated issues. The changes introduced in the 2016 English language curriculum have brought about mixed results so far since Ecuador still ranks the last out of 19 Latin American countries when it comes to English language proficiency. The 2016 curriculum may have been well-prepared, but its implementation has not been an unequivocal success from the point of the EFL teachers involved in our study. This is because they find that many of the objectives of the curriculum are unrealistic and unachievable. The participating primary and secondary school English teachers in the public education sector are conscious about the importance of English for the advancement of their students. They are prepared to apply the approaches and tools that they are familiar with, but they lack the skills and knowledge to apply new instructional approaches

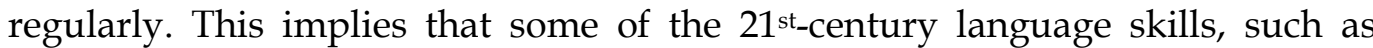
creativity and critical thinking, do not have much room in the English classes of the teachers interviewed. At the same time, teachers are mindful of the need to improve their skills, which would require effective in-service teacher training programs. The English teachers of the current study believe that training opportunities have dwindled in recent years. They would like to see educational policymakers provide regular and expanding opportunities for their continuing professional development. The findings of this exploratory study are, therefore, in line with those of the recent studies discussed above and draw attention to how exploratory research projects can identify and reiterate systemic issues to be resolved in order to achieve better performance levels in the Ecuadorian public education sector.

\section{Limitations}

This qualitative research study was conducted as a segment of a comprehensive, two-year project (between September 2018 and August 2020 - now extended), characterizing the different factors that facilitate or impede English learning in Ecuadorian public schools and, as such, can throw light only on a limited number of issues that surfaced in the exploratory phase. Furthermore, the 10 teachers whose responses were explored above, came from only three neighboring provinces of Ecuador representing approximately $10 \%$ of the country's population (Azuay, Morona Santiago, and Cañar). Owing to this, the opinions expressed by these primary and secondary school educators cannot be taken to represent the views of all English teachers in the country. 
A 'sister study' examined several other issues, such as the use of L1 in the classroom, the inclusion of special needs students in the teaching-learning process, and education policies (Sevy-Biloon et al., 2020). Therefore, the present study explored three other interrelated issues: the perceived importance of English, teaching strategies, and teacher training. As a result, the findings of the present research study cannot be generalized beyond the tentative conclusions that could be drawn from the interviews with 10 English teachers working in the public education sector (both in primary and secondary schools).

\section{Recommendations and Further Research}

The teachers' candid comments made in the interviews cannot be expected to provide an all-round picture, but can probably serve as a good starting point for further research that may aim to identify suggestions and recommendations as remedies to some of the problems that have been revealed. Regular and improved in-service teacher training schemes, with special regard to the fact that instruction has largely switched to emergency remote teaching since March 2020, could enhance the teaching-learning process of English. Setting up national and regional teacher associations could promote camaraderie, and professional development while classroom research, which is considered an accessible research approach for teacher-practitioners (Smith \& Rebolledo, 2018), could enhance teachers' engagement.

A further area of study might be investigating the effectiveness of the state scholarship system, especially that of the Go Teacher scheme. Such an inquiry could establish how far (if at all) it has contributed to improved classroom practices which, to date, do not appear to have been translated into higher levels of proficiency among learners of English in Ecuador. Hence, it is hoped that the findings of the present research study will be perceived as a meaningful contribution when future policies for EFL instruction in Ecuador are designed and implemented, and the resulting process will lead to more effective and efficient ways of teaching and learning English as an international language for the $21^{\text {st }}$ century.

\section{Acknowledgments}

The authors would like to thank all the participants of this research study for having supplied a wealth of data including their considered opinions on the topics discussed herewith. They are also grateful for the research and logistical support provided by the National University of Education, Ecuador (UNAE). The valuable comments and insights of the editors and reviewers, which significantly improved the manuscript, are also gratefully acknowledged.

\section{Notes}

1- The project, which ran from September 1, 2018 to August 31, 2020 (its extension beyond two years approved by the university) was entitled Caracterización de los factores que impiden o facilitan la enseñanza y aprendizaje de inglés como lengua extranjera en las escuelas de educación básica y bachillerato de la zona 6: Un estudio exploratorio [A characterization of the factors that impede or facilitate the teaching and learning of English as 
a Foreign Language in public schools in Zone 6 of Ecuador: An exploratory study]. Project code: VIP-UNAE-2017-55.

2- This is a role that has, to some extent, been taken over by the university whose researchers conducted the present research project.

3- On average, teachers' salaries were cut by $20 \%$.

4- The Go Teacher program involved about $14 \%$ of the 7000 English teachers working in the public education sector. See at

https://global.k-state.edu/dayofecuador/docs/go-teacher-fact-sheet.pdf

https://www.eltelegrafo.com.ec/noticias/sociedad/1/ecuador-ocupa-elpuesto-55-en-el-dominio-del-ingles

\section{References}

Acosta, H., \& Cajas, D. (2018). Analysis of teaching resources used in EFL classes in selected Ecuadorian universities. Indonesian Journal of Applied Linguistics, 8(1), 100-109. https://doi.org/10.17509/ijal.v8i1.11469

Beaumont, M., \& Chang, K. (2011). Challenging the traditional/communicative dichotomy. ELT Journal, 65(3), 291-299. https://doi.org/10.1093/elt/ccq091

British Council. (2013). The English effect. https:/ / www.britishcouncil.org/researchpolicy-insight/policy-reports/the-english-effect

British Council. (2015). English in Ecuador: An examination of policy, perceptions and influencing factors. https://www.teachingenglish.org.uk/sites /teacheng/files/English\%20in\%20Ecuador.pdf

Buendía, X. P., \& Macías, D. F. (2019). The professional development of English language teachers in Colombia: A review of the literature. Colombian Applied Linguistics Journal, 21(1), 98-111. https://doi.org/10.14483/22487085.12966

Burgin, X., \& Daniel, M. (2017). Exploring English language teaching in an Ecuadorian urban secondary institution. GIST Education and Learning Research Journal, 14, 107-134. https://doi.org/10.26817/16925777.364

Calle, A. M., Calle, S., Argudo, J., Moscoso, E., Smith, A., \& Cabrera, P. (2012). Los profesores de inglés y su práctica docente: Un estudio de caso de los colegios fiscales de la ciudad de Cuenca, Ecuador [English teachers and their teaching practice: A case study of public secondary schools in Cuenca, Ecuador]. https://doi.org/10.18537/mskn.03.02.01

Carrier, M. (2018). Improving English language proficiency in state schools: Policy and systemic implementation. In H. Rojas \& J. Hernández-Fernández (Eds.), English public policies in Latin America: Looking for innovation and systemic improvement in quality English language teaching (pp. 10-29). British Council Mexico. https://www.teachingenglish.org.uk/sites/teacheng/files/RPD_Publication.pd $\mathrm{f}$

Chan, K. L. (2016). Power Language Index. Which are the world's most influential languages?. http://www.kailchan.ca/wp-content/uploads/2016/12/Kai-Chan_PowerLanguage-Index-full-report_2016_v2.pdf

Chiruguru, S. B. (2020). The essential skills of 21st century classroom (4Cs). https:// doi.org/10.13140/RG.2.2.36190.59201

Cronquist, K., \& Fiszbein, A. (2017). English language learning in Latin America. https://www.thedialogue.org/wp-content/uploads/2017/09/EnglishLanguage-Learning-in-Latin-America-Final-1.pdf

Crystal, D. (2003). English as a global language (2nd ed.). Cambridge, UK: Cambridge University Press. https://doi.org/10.1017/CBO9780511486999 
Dikilitaş, K., \& Erten, I. H. (Eds.). (2017). Facilitating in-service teacher training for professional development (1 $1^{\text {st }}$ ed.). Hershey, PA: IGI Global. https:// doi.org/10.4018/978-1-5225-1747-4

Dudeney, G. (2015). 21 st century skills and digital literacy in action. https://www.teachingenglish.org.uk/article/gavin-dudeney-21st-centuryskills-digital-literacy-action

Education First. (2019). EF English Proficiency Index. https://www.ef.com/assetscdn /WIBIwq6RdJvcD9bc8RMd/legacy/_/ /media/centralefcom/epi/download s/full-reports/v9/ef-epi-2019-english.pdf

Education First. (2020a). EF English Proficiency Index. https://www.ef.com/ca/epi/regions/latin-america/ecuador/

Education First. (2020b). EF English Proficiency Index. https://www.ef.com/ca/epi

Erdoğan, V. (2019). Integrating 4C skills of 21st century into 4 language skills in EFL classes. International Journal of Education and Research, 7(11), 113-124.

Godau, R. I. (2003). Qualitative data analysis software: MAXqda. Qualitative Research Journal, 4(1), 66-72. https://www.researchgate.net/publication/259185207_Qualitative _Data_Analysis_Software_MAXqda

Gómez Ponce, L. (2020). Un año de reduccionesen el presupuesto para los sectores sociales. https://www.gastopublico.org/informes-del-observatorio/2020-un-ano-dereducciones-en-el-presupuesto-para-los-sectoressociales\#: :text=En $\% 202017 \% 20$ fue $\% 20 \mathrm{de} \%$ 20USD,anterior $\% 2 C \% 20$ con $\% 20$ USD $\% 2032.530 \% 20$ millones

Halim, A. O. J. (2017). Ecuador and bilingualism a "mirage or reality": A critical look at English as a foreign language. Universidad Politécnica Estatal del Carchi. Ecuador. https://doi.org/10.32645/13906925.123

Herrell, A. L., \& Jordan, M. L. (2020). 50 strategies for teaching English language learners

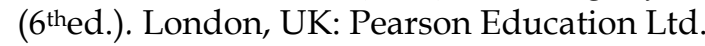

Hinkel, E. (2006). Current perspectives on teaching the four skills. TESOL Quarterly, 40(1), 109-131. https://doi.org/10.2307/40264513

Iturralde, P. J. (2020). Ecuador, COVID-19 and debt. https://www.eurodad.org/ecuador_covid19_and_debt

Koç, E. M. (2016). A general investigation of the in-service training of English language teachers at elementary schools in Turkey. International Journal of Elementary Education, 8(3), 455-466. https:/ /files.eric.ed.gov/fulltext/EJ1096582.pdf

Macías Mosquera, K. Y., \& Villafuerte Holguin, J. S. (2020). Teaching English language in Ecuador: A review from the inclusive educational approach. Journal of Arts and Humanities, 9(2), 75-90. https://doi.org/10.18533/journal.v9i2.1854

Mai, H. T. N. (2017). Contextual factors affecting the implementation of communicative language teaching in Vietnam. EFL Journal, 2(2), 103-113. https://efljournal.org/index.php/efljournal/article/view/40/pdf

McCormick, C. (2013). Countries with better English have better economies. https://hbr.org/2013/11/countries-with-better-english-have-better-economies

Ministerio de Educación del Ecuador [Ministry of Education, Ecuador]. (2013). National English curriculum guidelines. https://educacion.gob.ec/wpcontent/uploads/downloads /2013/04/Curriculum_Guidelines-EFL-1.pdf

Ministerio de Educación del Ecuador [Ministry of Education, Ecuador]. (2016a). English as a Foreign Language. https:/ / educacion.gob.ec/wpcontent/uploads/downloads/2016/03/EFL1.pdf 
Ministerio de Educación del Ecuador [Ministry of Education, Ecuador]. (2016b). Currículo de los niveles de Educación Obligatoria [Curriculum for the Compulsory Levels of Education]. https://educacion.gob.ec/wpcontent/uploads/downloads/2016/03/Curriculo1.pdf

Norris, L. (2019). Promoting 21st century skills. https://www.teachingenglish.org.uk/sites/teacheng/files/J105_12_Promoting _21_Skills_web.pdf

Ortega, D. P., \& Minchala, B. E. (2019). Explorando las Aulas de Clase de Inglés en Cañar: Currículo, instrucción y aprendizaje. [Exploring English language classrooms in Cañar: Curriculum, instruction and learning. CIENCIA UNEMI, 12(30), 57-73.

http://ojs.unemi.edu.ec/index.php/cienciaunemi/article/view/772

Promtara, N., \& Suwannarak, K. (2018). Thai students and teachers' perceptions of learning and teaching English through the communicative language teaching approach. NIDA Journal of Language and Communication, 23(33), 23-42. https:// so04.tci-thaijo.org/index.php/NJLC/article/view/135387/101154

Raud, N., \& Orehhova, O. (2017). In-service training of teachers of English as a foreign language in Estonia: Mapping of trends and opportunities. Problems of Education in the $21^{\text {st }}$ century, 75(2), 194-203.

Richards, J. C. (2015). Key issues in language teaching. Cambridge, UK: Cambridge University Press.

Richards, J. C., \& Farrell, T. S. C. (2005). Professional development for language teachers: Strategies for teacher learning. Cambridge, UK: Cambridge University Press.

Rojas, J., \& Hernández-Fernández, J. (2018). The importance of English as a second language in Latin America. In H. Rojas \& J. Hernández-Fernández (Eds.), English public policies in Latin America: Looking for innovation and systemic improvement in quality English language teaching (pp. 10-29). British Council Mexico. https://www.teachingenglish.org.uk/sites/teacheng/files/RPD_Publication.pd $\mathrm{f}$

Rosero, S. I., Embleton, L., Rivera, I. M., \& Ponce, R. R. (2004). Our world through English. Quito, Ecuador: Edimpres.

Sakui, K. (2004). Wearing two pairs of shoes: Language teaching in Japan. ELT Journal, 58(2), 155-163. https:// doi.org/10.1093/ elt/58.2.155

Sarab, M. R. A., Monfared, A., \& Safarzadeh, M. M. (2016). Secondary EFL school teachers' perceptions of CLT principles and practices: An exploratory survey. Iranian Journal of Language Teaching Research, 4(3), 109-130.

Sevy-Biloon, J., Recino, U., \& Muñoz, C. (2020). Factors affecting English language teaching in public schools in Ecuador. International Journal of Learning, Teaching and Educational Research, 19(3), 276-294. doi:10.26803/ijlter.19.3.15

Smith, R., \& Rebolledo, P. (2018). A handbook for exploratory action research. London, UK: British Council.

https://www.teachingenglish.org.uk/sites/teacheng/files/pub_30510_BC \%20Explore\%20Actions\%20Handbook\%20ONLINE\%20AW.pdf

Soto, S. T., Encalada, M. A. R., Sarmiento, M. A., Galimberti, J. V., \& Cárdenas, S. S. E. (2020). Understanding EFL students' learning through classroom research: Experiences of teacher-researchers. http://repositorio.utmachala.edu.ec/handle/48000/15504

Starkey, H. (2010). Language learning for human rights and democratic citizenship. In C. Rosi Solé \& J. Fenoulhet (Eds.), Mobility and localisation in language learning (pp. 79-106). Oxford, UK: Peter Lang. 
Suasnavas, K. (2018). The use of technological tools: Movie Maker and weblogs to foster social interaction in the classroom. Kronos - The Language Teaching Journal, 1(01), 45-52.

Vogt, W. P. (1999). Dictionary of statistics and methodology: A non-technical guide for the social sciences ( $2^{\text {nd }}$ ed.). London, UK: Sage Publications.

\section{Appendix 1}

Interview questions

1. What level or levels do you teach?

2. What is your most common way to teach an English lesson? Please, describe and give examples.

3. During your English lessons, what is the time percentage you use to explain, and what is the time percentage you let your students work independently?

4. Do you have your students practice in pair and group work? Explain.

5. What are the factors that help or impede the student learning in the classroom?

6. Do you use Spanish during your lessons? In one teaching hour, how much Spanish do you use?

7. What advantages and disadvantages have you experienced with the use of Spanish in the English lessons?

8. To what extent do you think your teaching practice facilitate or impede the English language learning? Please, describe and give examples.

9. Do you use a textbook? Explain why.

10. To what extent do you think that the current educational policies encourage or inhibit the English language learning?

11. How much importance is given to English learning at the institution where you work? Do the students' parents and the school academic authorities give importance to the English learning?

12. Have you received any formal training by the Ministry of Education?

13. After the curriculum implementation in 2016, have you received any training? Have you personally found any extra training for your performance?

14. Is it important that Elementary and High School level students learn English? What is the existing perception about this topic in the country? Support your answer, please.

15. How do you use the existing infrastructure in the institution to teach English?

16. What is the role of the infrastructure for learning English? Support your answer and give examples, please. 